\title{
Pedal luring in the leaf-frog Phyllomedusa burmeisteri (Anura, Hylidae, Phyllomedusinae)
}

\author{
Jaime Bertoluci \\ Departamento de Zoologia, Universidade Federal de Minas Gerais. Caixa Postal 486, Belo Horizonte, MG, Brazil, \\ 31270-901. E-mail: bertoluc@icb.ufmg.br.
}

Keywords - Phyllomedusa burmeisteri, Phyllomedusinae, Hylidae, Anura, pedal luring, prey capture, feeding behavior.

Luring behavior as a strategy of prey capture has evolved independently in several squamate lineages, including pygopodid lizards (Murray et al. 1991), and boid (Murphy et al. 1978, Radcliffe et al. 1980), viperid (Greene and Campbell 1972, Heatwole and Dawson 1976, Henderson 1970, Sazima 1991), elapid (Carpenter et al. 1978), and colubrid snakes (Sazima and Puorto 1993). Bavetz (1994) reported pedal luring related to predation in ambystomatid salamanders. In anurans, this feeding behavior has been described only for the terrestrial leptodactylid frogs Ceratophrys calcarata (Murphy 1976) and C. ornata (Radcliffe et al. 1986). Pedal luring apparently does not occur in the terrestrial leptodactylids Caudiverbera caudiverbera and Odontophrynus americanus tested by Radcliffe et al. (1986). Hödl and Amézquita (2001) reviewed visual signaling in anuran amphibians including signals addressed toward potential prey. Here I describe for the first time pedal luring behavior in a hylid frog, the highly arboreal leaf-frog Phyllomedusa burmeisteri.

Observations were made of a captive adult female ( $82 \mathrm{~mm}$ snout-vent length) collected on 03 November, 2001 in the Serra do Caraça, an Atlantic forest reserve of Southeastern Brazil;

Received 19 April 2002

Accepted 18 December 2002 the frog was maintained in a $60 \times 30 \times 37-\mathrm{cm}$ glass terrarium containing soil and a bromeliad. On the fourth day of acclimation at $2300 \mathrm{~h}$ and under dim light, pedal luring was observed in response to offering the frog an individual adult cricket (Orthoptera); the same observations were made the next night. During the next three days, the frog fed on domestic cockroaches (Blattaria), but pedal luring was not observed in these circumstances. Larval mealworms (Tenebrio sp.) also were offered to the frog, but always were refused.

Phyllomedusa burmeisteri is a sit-and-wait predator that typically perches with its hands and feet firmly grasping the substrate while searching for prey. When the frog noticed the cricket in the terrarium, it faced it frontally. Pedal luring consisted of slow undulations of Toes IV and V of each foot alternately. Each complete display lasted about $5 \mathrm{~s}$. As the cricket approached the frog, toe movements became more frequent. White circles on the dorsal surface of expanded toe discs contrast with the overall dorsal green coloration of the frog; thus, the toes and toe movements are perceptible under low light conditions (Figure 1). The distal lateral fringe of Toe $\mathrm{V}$ also is whitish; the fringe, combined with the white circle, resembles a vermiform animal. I did not observe any finger movements during the luring behavior, but it is possible that they occur because the fingertips also have white circles on them. 
The crickets were captured by tongue protraction accompanied by a slow and rigid movement forward of the animal as soon as the insects were at a reachable distance. The frog seems to facilitate swallowing the prey by posturing the body and head almost vertically and also by pulling its eyes in.

Luring behavior is typical of relatively sluggish, sit-and-wait anuran predators that ambush preys more agile than themselves (Murphy 1976, Radcliffe et al. 1986). This is the case of Phyllomedusa species, which are highly arboreal hylids with opposable thumbs; these frogs feed primarily on orthopterans, cockroaches and spiders (Parmelee 1999). I hypothesize that white circles on the dorsal surface of digital discs in $P$. burmeisteri and other Phyllomedusa species make the digits more visible when they are moved and thereby enhance prey attraction. When the frog rests by day, the digital markings are concealed under the body, as in visually signaling frog species, where conspicuous coloration remains hidden during resting positions (Hödl and Amézquita 2001).

In the terrestrial leptodactylid frog Ceratophrys calcarata pedal luring includes lifting the hind limb above substrate during toe movements (Murphy 1976); this posture is necessary because Ceratophrys remains partially hidden in the leaf litter and the pedal movements would not be visible otherwise. Phyllomedusa burmeisteri moves the same toes (i.e. IV and V) in pedal luring as does $C$. calcarata (Murphy 1976); however, Ceratophrys ornata uses Toes II, III, and IV. The occurrence of pedal luring in these three species suggests that Murphy (1976) was incorrect in his suggestion that pedal luring in $C$. calcarata might be a behavioral pattern acquired by the single individual that he observed. Instead, it seems more likely that pedal luring behavior in $P$. burmeisteri and Ceratophrys represents an innate action pattern (Barlow 1977) triggered by the sight of prey and which functions as a lure to any susceptible prey, as suggested by Radcliffe et al. (1986) for C. ornata.

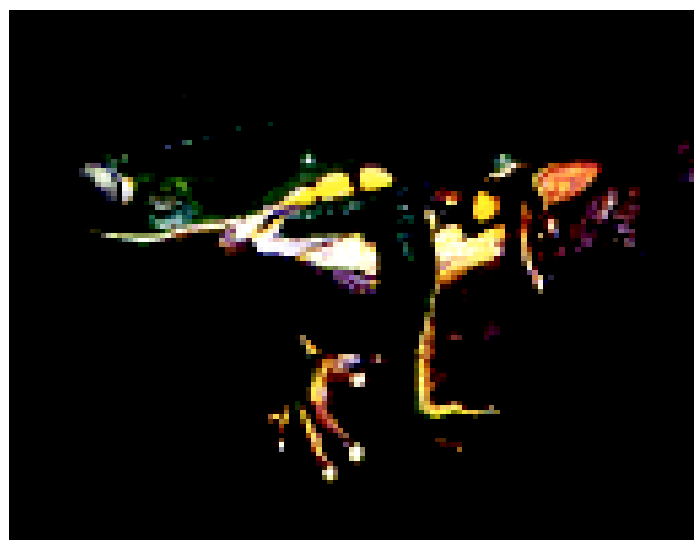

Figure 1 - Adult female Phyllomedusa burmeisteri used in observations of pedal luring behavior showing the high visibility of toe and finger tips and the fringe of Toe $\mathrm{V}$ under low light conditions.

Because Murphy (1976) observed pedal luring in Ceratophrys calcarata only in the presence of a leptodactylid, Pleurodema sp., and not of crickets, he concluded that anurans that feed mainly on invertebrate prey would not require digital luring. However, Bavetz (1994) observed pedal luring in the salamanders Ambystoma talpoideum and A. tigrinum in presence of crickets, and both larval and adult mealworms. I argue that pedal luring in anurans is not associated to prey type, but to the necessity to provoke the prey to approach predators that cannot readily reach their prey. An arboreal environment challenges many types of predators to reach their prey. Phyllomedusinae is the only hylid lineage that has highly protrusible tongues (Deban and Nishikawa 1992). It seems reasonable that such a tongue and pedal luring might be associated with the arboreal habits and relatively slow body movements of these anurans.

Pedal luring in frogs also seems to be associated with cryptic coloration, because both Ceratophrys spp. (Murphy 1976, Radcliffe et al. 1980) and Phyllomedusa burmeisteri are cryptically colored; this same pattern is 
observed in snakes that use caudal luring (Sazima and Puorto 1993). In this context, these anurans may have evolved pedal luring behavior to increase their effective encounter rate with prey items (Radcliffe et al. 1986). I suggest that pedal luring may occur in other species of Phyllomedusinae, like Phyllomedusa bicolor, as well as other sit-and-wait anurans.

\section{Acknowledgements}

I thank Marco Canellas for collecting and providing a live frog for my use, and Regina Vincent for her part in caring for the animal. Vanessa Verdade, Vinícius Xavier and José Cassimiro helped to assemble the bibliography. Miguel Trefaut Rodrigues and Marcos Rodrigues provided welcome comments on the manuscript and Linda Trueb, Walter Hödl, and Barbara Zimmerman reviewed it.

\section{References}

Bavetz, M. J. 1994. Pedal movements in two ambystomatid salamanders. Journal of Herpetology 28: 504-506.

Barlow, G. W. 1977. Modal action patterns. Pp. 98-134 in T. Sebeok (ed.), How Animals Communicate. Bloomington. Indiana University Press.

Carpenter, C. C., J. B. Murphy and G. C. Carpenter. 1978. Tail luring in the death adder, Acanthopis antarcticus (Reptilia, Serpentes, Elapidae). Journal of Herpetology 12: 574-577.

Deban, S. M. and K. C. Nishikawa. 1992. The kinematics of prey capture and the mechanism of tongue protraction in the green tree frog Hyla cinerea. Journal of Experimental Biology 170: 235-256.
Greene, H. W. and J. A. Campbell. 1972. Notes on the use of caudal lures by arboreal green pit vipers. Herpetologica 28: 32-34.

Heatwole, H. and E. Dawson. 1976. A review of caudal luring in snakes with notes on its occurrence in the Saharan sand viper, Cerastes vipera. Herpetologica 32: 332-336.

Henderson, R. W. 1970. Caudal luring in juvenile Russell's viper. Herpetologica 26: 276-277.

Höd1, W and A. Amézquita. 2001. Visual signaling in anuran amphibians. Pp. 121-141 in M. J. Ryan (ed.), Anuran Communication. Washington, Smithsonian Institution Press.

Murphy, J. B. 1976. Pedal luring in the leptodactylid frog, Ceratophrys calcarata Boulenger. Herpetologica 32: 339-341.

Murphy, J. B., G. C. Carpenter and J. C. Gillingham. 1978. Caudal luring in the Green Tree Python, Chondrophython viridis (Reptilia, Serpentes, Boidae). Journal of Herpetology 12: 117-119.

Murray, B. A., S. D. Bradshaw, and D. H. Edward. 1991. Feeding behavior and the occurrence of caudal luring in Burton's pygopodid Lialis burtonis (Sauria: Pygopodidae). Copeia 1991: 509-516.

Parmelee, J. R. 1999. Trophic ecology of a tropical anuran assemblage. Scientific Papers of the Natural History Museum of the University of Kansas 11: 1-159.

Radcliffe, C. W., D. Chiszar and H. B. Smith. 1980. Preyinduced caudal movements in Boa constrictor with comments on the evolution of caudal luring. Bulletin of Maryland Herpetological Society 16: 19-22.

Radcliffe, C. W., D. Chiszar, K.Estep, J. B. Murphy, and H. M. Smith. 1986. Observations on pedal luring and pedal movements in leptodactylid frogs. Journal of Herpetology 20: 300-306.

Sazima, I. 1991. Caudal luring in two Neotropical vipers, Bothrops jararaca and B. jararacussu. Copeia 1991: 245-248.

Sazima, I. and G. Puorto. 1993. Feeding technique of juvenile Tropidodryas striaticeps: probable caudal luring in a colubrid snake. Copeia 1993: 222-226. 